\title{
THE APPLICATION OF INDIRECT FEEDBACK TO IMPROVE STUDENTS' PARAGRAPH WRITING
}

\author{
Mega Mulianing Maharani \\ Sultan Agung Islamic University \\ Semarang Indonesia \\ megamulianing@unissula.ac.id
}

\begin{abstract}
Writing is one of the important skills should be mastered by students of English education program. Mastering writing forces students to be able to produce good paragraph. Paragraph is said to be good if it is well organized. Organizing good paragraph is the problem faced by the second semester students of English education of Sultan Agung Islamic University. Based on that problem, the writer decided to apply indirect feedback to the students' paragraph writing. The writer wants to know the way indirect feedback applied to improve the students' paragraph writing. The writer used action research to come up to the objective of the research. There was one cycle of the research which consisted of planning, acting, observing, and reflecting. The writer adopted the steps of analyzing the data as proposed by Burns (2010) which consisted of assembling, coding, comparing, building meaning and interpretation and reporting the outcomes. The result was that the way the writer used underline to the students' writing could improve the students' paragraph writing. The students could provide correct final revision of their inappropriate writing.
\end{abstract}

Keywords: Indirect feedback, paragraph writing

\section{INTRODUCTION}

Nowadays, many people learn English. For people who intentionally choose English as the course, such as students of English department it is very interesting for them to have English every day. Learning English makes them proud to be the real international people. Even English is not their first language they like to study it in formal school, university. The students gain the knowledge of mastering it through some aspects. They are capable of receiving and learning not only the respective skills but also the productive skills. They are formed to be a person who can use both of the aspects, namely, listening, reading, speaking and writing. In the context of foreign 
language, to be as that person is not as easy as they smile. They need extra effort to be able to listen, read, speak and write as well as native alike.

One of the skills that forces students extra energy to master it is writing. Writing is a means of communication. Students can do many things in their life to communicate by using writing. For example, they write their opinion to share their feeling, they write their problem to be their status on their social media, they send a message to their friend about their happiness and sadness, they write their experience into a story, etc. Cohen and Miller (2001) consider that writing is an important skill since it is an active communication or social process involving discussion, interaction with the teachers, group work, pair work, and peer evaluation. In another words, it can be said that those activities prove that writing has an important role in human life.

In order to come up to the important role of writing, the students should pay attention to the process of writing. According to Rachmajanti and Sulistyo (2008), writing is a process. This process consists of planning, drafting, editing, and finally writing a final version. Those processes are very complex (Richards and Schmidt, 2002). It means that various operations cause the final draft. To have good final draft, the students should think about the coherence between the words of the sentences which are arranged in a particular order and linked together in certain ways. In this respect, Bailey (2003) suggests that students have to master the paragraph writing that is needed.

In university level, paragraph writing is as one of the subjects has to be learned by students. Paragraph writing is a process of putting sentences into a good order. Oshima and Hogue (2006) state that a paragraph is a group of related sentences that discuss one main idea. In order to have a good paragraph, students should pay attention to the main parts of paragraph. There are three parts of a good paragraph. Oshima and Hogue (2006) point that the three parts of paragraph are topic sentence, supporting sentences, and concluding sentence. The topic sentence explains the topic and controlling idea of the paragraph. The supporting sentences explain the topic sentence. The concluding sentence serves two things, to signal the end of the paragraph and to inform the readers with the most important ideas. From those three 
Maharani, The Application of Indirect Feedback to Improve Students'...

parts of paragraph, one of the students' mistakes is that they fail to support their ideas adequately. They need to use specific details to be thorough and convincing such as providing examples, statistics, and quotation. They may choose one of the details or use all of them to make their paragraph smooth.

In paragraph writing, the writer found that the university students especially the second semester students of English education program had many difficulties. The difficulties of deciding the appropriate tense; providing correct verb, pronoun, determiner, plural, there is, there are; changing Indonesian sentences into English sentences which meant that their writing often seemed as English-Indonesian sentences; creating meaningful sentences; creating complete sentences; providing active into passive sentences and vice versa; deciding the appropriate words choice; creating good sentences which consists of modal; creating uncorrelated sentences; creating correct direct-indirect sentences; and creating consistent terms are their problems.

Moreover, the other problem deals with the difficulties in linking one paragraph into other paragraphs. The problems faced by the students are not surprising since they face different language, English, which is not their first language. They do not have clear understanding about the characteristics of writing. Moreover, they are not provided insufficient linguistic input to write in English successfully. For some students, writing using English is not something new because they like it. However, for some students, writing using English is something new because they did not like it. As the result, being students of English education program whether or not they like to write using English, it is a must for them to be able to write good English paragraphs.

As the lecturer of paragraph writing, the writer has decided to work on one strategy to help the students overcome their writing problem. The writer decided to use feedback to help the students. Nunan (2003) suggests that the teacher of writing can help students by providing constructive and meaningful feedback. Feedback is kinds of technique that are generally used to respond the students' writing (Ravand and Rasekh, 2011). In the very early meeting of paragraph subject, the writer did not give any feedback to the students' writing. The writer only wrote the scoring rubric to the students' writing. On 
the next writing assignment, the writing compare their writing which contained the scoring rubric and the new writing in order to see their errors. The result showed that they still provided the same errors. Based on those phenomena, therefore, the writer decided to use feedback because the writer wanted to give response on the students' writing which could help the students to improve their paragraph writing. They are going to be happy because feedback asks them to realize their misleading and confusing of their writing. Feedback is decisive factor in the attainment of language fluency and accuracy (Salteh and Sadhegi, 2012)

The feedback used in this research was indirect feedback or implicit feedback. The writer did not give the correction directly to the students' writing but the writer used underline. The purpose of using indirect feedback was that the writer wanted the students to give their self-correction. By giving their selfcorrection, they were thinking hardly to solve their problems. They might ask their friends for the solution or they might reverse back to their prior knowledge of the previous writing subject or even grammar subject. From the students' final revision, the writer could see that during the revision activity the students could understand the best revision in order to provide good writing after they received the feedback.

In knowing the students' understanding of the misleading writing, the writer applied action research. The reason was that the writer wanted to know the process of the students had during the revision time. The writer would find their difficulties of making good descriptive paragraphs writing. Therefore, the writer decided to have the second semester students of English education program of Sultan Agung Islamic University as the participants. The reason of choosing them was because paragraph writing is the subject that has to be fulfilled by the second semester students. The writer took one class as the sample of the research which consisted of 19 students.

\section{DISCUSSION}

The writer used action research as the design of this study. The reason was that the writer wanted to extend her teaching skill and gain more understanding of herself as a lecturer. By doing an action research, the writer 
Maharani, The Application of Indirect Feedback to Improve Students'...

could think about what happened in the classroom then the writer could do better for that happening. It is in line with what Burns (2010) mentions that one of the main aims of action research is to identify a problematic situation or issue faced by the participants. As the result, the end of the research was to bring about changes to the students' problem. From this action research, the writer wanted to change the students' writing understanding after they revised their writing which was based on the writer's feedback. By doing the revisions of the feedback, they were in the process of making their writing better.

There is cycle of action research. The first cycle may become a continuing, or iterative, spiral of cycles which recur until the action writer has achieved a satisfactory outcome and feels it is time to stop. Each cycle consists of four main phases, namely, planning, action, observation and reflection. The writer used the cycles design as proposed by Burns (2010) that the elaboration of each cycle is as follows:

a. Planning

In planning, the writer identified the problem of second semester students in paragraph writing class. The focus of the phase was to find out the students' difficulties in writing paragraph.

b. Action

In action, the writer applied the planning over an agreed period of time.

c. Observation

In observation, the writer observed systematically the effects of the action and documenting the context, actions and opinion which are involved. In this phase, the writer got information happened in the classroom.

d. Reflection

In reflection, the writer reflected, evaluated, and described the effects of the action in order to make sense of what has happened and to understand the issue that the writer had explored more clearly.

In applying those cycles, the writer needed an instrument. The instrument used in this research was classroom document. There are many written document that can be categorized into classroom document. Burns (2010) clarifies that classrooms are full of all kinds of written documents syllabus guidelines, lesson plans, textbooks, readers, students' written texts, 
exercises, illustrations, maps, dictionaries and so on. The writer used students' paragraph writing especially descriptive paragraph as the instrument of this research. From the students' descriptive paragraph, the writer was able to know the students' writing difficulties and their writing improvement after the writer gave feedback to the students. Hence, the writer could diagnose the areas to be focused on to assist the students further.

There was one cycle used in this research and it was done into four main phases which categorized into planning, acting, observing, and reflecting. In planning phase, the writer identified the problem of the second semester students in paragraph writing class. The focus of the phase was to find out the students' difficulties in writing paragraph. To gain the purpose, the writer handled a discussion with the second semester students on the first day of the research. During the discussion, the writer made notes of their problem in writing paragraph. The results of the discussion were that the students were not capable of:

1. deciding the appropriate tense,

2. providing correct verb, pronoun, determiner, plural, there is, there are,

3. changing Indonesian sentences into English sentences which meant that their writing often seemed as English-Indonesian sentences,

4. creating meaningful sentences,

5. creating complete sentences,

6. providing active into passive sentences and vice versa,

7. deciding the appropriate words choice,

8. creating good sentences which consists of modal,

9. creating uncorrelated sentences,

10. creating correct direct-indirect sentences,

11. creating consistent terms, and

12. creating correct English words.

The information above was used to order the action phase. The writer thought about the action would be implemented in the classroom.

At the time the writer got the students' difficulties, the writer decided to make a writing activity to check the reality. In the writing activity, the writer asked the students to write a descriptive paragraph about the canteen of the 
university, Pumanisa. They needed to describe it by giving their point of view which was based on the real condition of the canteen. As soon as they finished their writing, the writer gave indirect feedback to them. The writer had this activity in the acting phase. The writer underlined the students' work and the students revised their inappropriate writing into better writing. This activity was aimed to know whether or not the students understood the feedback and whether or not they could provide the correct writing. The result of the students' writing and the writer's feedback are as follows:

Table 1. The Students' Writing and the Writer's feedback

\begin{tabular}{|c|c|}
\hline Category & Sentences and Feedbacks \\
\hline $\begin{array}{l}\text { deciding the } \\
\text { appropriate tense }\end{array}$ & $\begin{array}{l}\text { 1. Pumanisa was opened. } \\
\text { 2. The students spent } \\
\text { 3. Then if colleges or lecturers another university will say } \\
\text { that our canteen had the best quality } \\
\text { 4. We went to the first floor. } \\
\text { 5. This place served } \\
\text { 6. Therefore, Pumanisa provided almost all. }\end{array}$ \\
\hline $\begin{array}{l}\text { providing correct } \\
\text { verb, pronoun, } \\
\text { determiner, plural, } \\
\text { there is, there are }\end{array}$ & 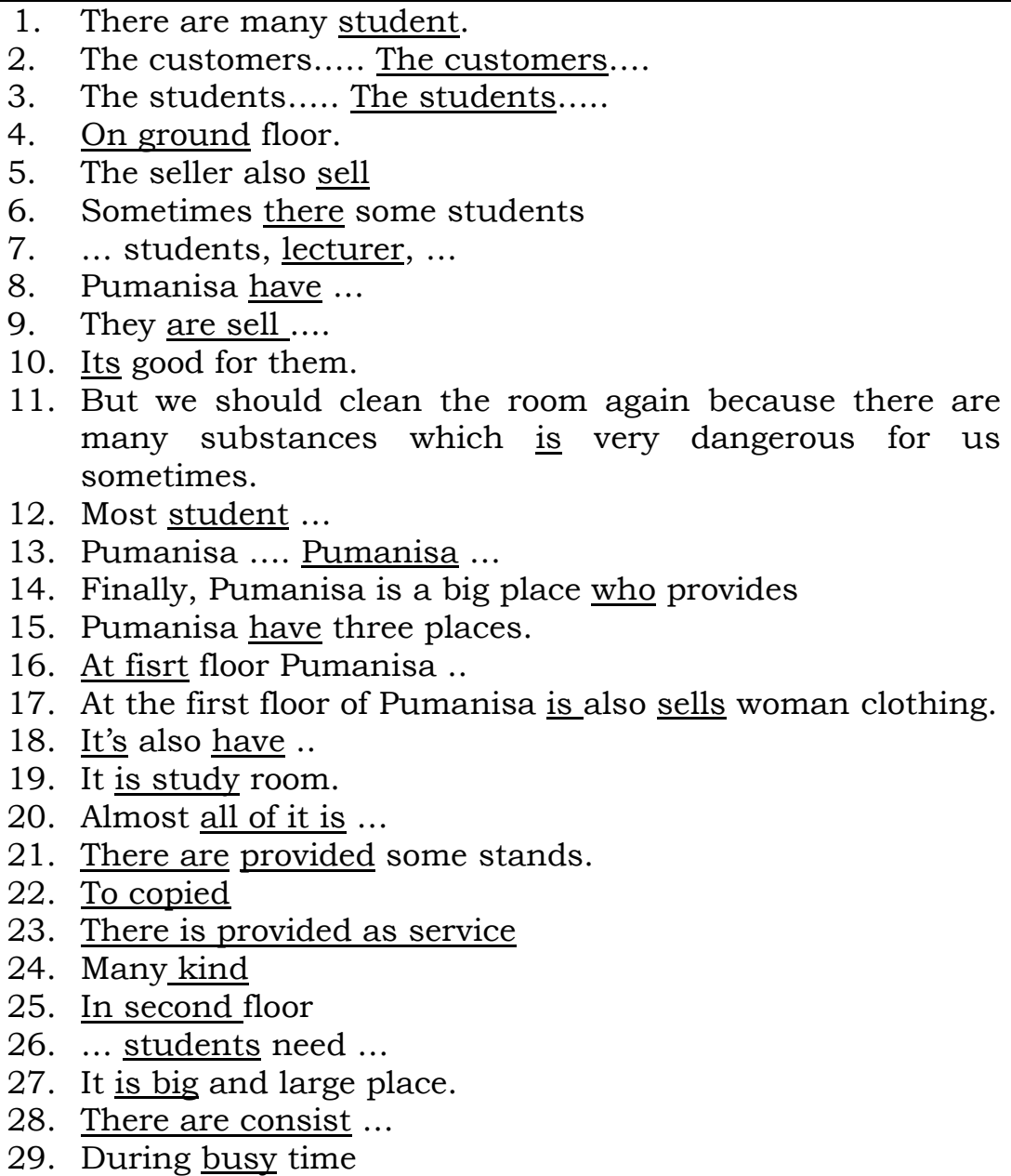 \\
\hline
\end{tabular}


30. Price in Pumanisa is quiet cheap

31. Pumanisa open

32. It consist

33. If their forgets use socks

34. Two faculty

35. ... lecturer room ..

36. It place has unique ...

37. The building is consists

38. It is open

39. It is give $\ldots$

40. The canteen not only serve food and drink but also ....

41. It's can be

42. This place serve for person who want pay ..

changing

Indonesian sentences English sentences which meant that their writing often seemed as EnglishIndonesian sentences

1. It can make them like going there.

2. There are always full of students when in the rest time.

3. On the other hand, on the second floor provides like food court.

4. On the third floor uses for study for the students of health.

5. It has many food stalls, coffee shop inside that.

6. It makes colleges and lecturers are easily to buy ...

7. Without go outside campus and buy some of foods or drinks with expensive prices.

8. Then if colleges or lecturers another university will say that our canteen had the best quality.

9. On the last floor, it's just there for rooms.

10. The three rooms for process of learning students.

11. So that place make easy for students to complete their necessary in campus.

12. It is used to teaching and learning activities by a faculty.

13. You can searching, printed, copying your assignments in there.

14. But sometimes difficult to find ...

15. To have eat

16. Many people in there

17. Just the students of the doctor can enter in that room

creating meaningful 1. It can make them like going there.

sentences

2. This is completely necessary for colleges to buy something effectively.

3. The students can be used to talk with their friends and there is very crowded.

4. Skin can their buy in first floor

creating complete 1. Students who haven't their breakfast.

sentences 2 . Multi function canteen because ...

3. ... make an assignment, but we don't have enough time.

4. It is used to teaching and learning activities by a faculty.

5. But sometimes difficult to find ...

6. The sellers very busy

7. In second floor many canteen you can buy food and drink

8. All of the people need something to office tool must buy to the first floor.

9. Pumanisa is a place that very comfortable.

providing active into 1 . We know that usual canteen is only served food.

passive sentences 2. On the third floor uses for study for the students of 


\begin{tabular}{|c|c|}
\hline and vice versa & $\begin{array}{l}\text { health. } \\
\text { 3. There are provided some stands } \\
\text { 4. It located .... } \\
\text { 5. The mini market in first floor located in front of ... } \\
\text { 6. The third floor is use for ... } \\
\text { 7. Inside the room is complete .... }\end{array}$ \\
\hline $\begin{array}{lr}\begin{array}{l}\text { deciding } \\
\text { appropriate } \\
\text { choice }\end{array} & \text { words } \\
\end{array}$ & $\begin{array}{l}\text { 1. } \text { Floor two, floor three, } . . . \\
\text { 2. Equipment lecture } \\
\text { 3. } \quad \ldots \text { has own part ... } \\
\text { 4. If their forgets use socks } \\
\text { 5. Second floor is the place I thing. } \\
\text { 6. I don't know much for this room. } \\
\text { 7. } \\
\end{array}$ \\
\hline $\begin{array}{lr}\text { creating } & \text { good } \\
\text { sentences } & \text { which } \\
\text { consist of modal }\end{array}$ & $\begin{array}{l}\text { 1. You can searching, printed, copying your assignments in } \\
\text { there. } \\
\text { 2. You can finding .... } \\
\text { 3. We can using .... }\end{array}$ \\
\hline $\begin{array}{l}\text { creating } \\
\text { uncorrelated } \\
\text { sentences }\end{array}$ & $\begin{array}{l}\text { 1. It is the central canteen. Therefore, every faculty provides } \\
\text { 2mall canteen also. } \\
\text { In there, so many comfortable tables and chairs that we } \\
\text { can enjoy our talking. And order food and drinks that we } \\
\text { want. }\end{array}$ \\
\hline $\begin{array}{l}\text { creating correct } \\
\text { direct-indirect } \\
\text { sentences }\end{array}$ & 1. One of my friend told me she said that \\
\hline $\begin{array}{l}\text { creating consistent } \\
\text { terms }\end{array}$ & $\begin{array}{l}\text { 1. Students (in the previous sentences) - student (in another } \\
\text { sentences) }\end{array}$ \\
\hline $\begin{array}{l}\text { creating correct } \\
\text { English words. }\end{array}$ & 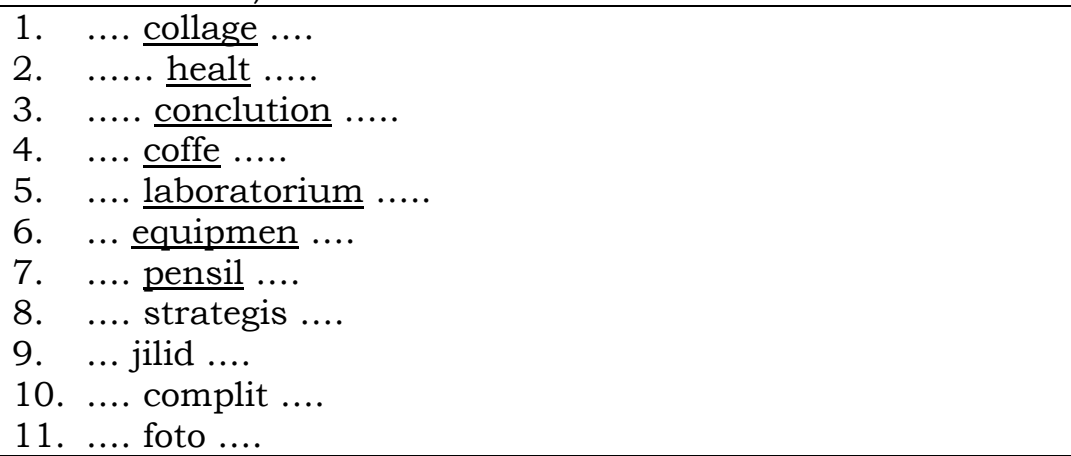 \\
\hline
\end{tabular}

After the students put the revision on their inappropriate writing, the writer went to the third phase what so called as the observation phase. Here, the writer observed systematically the effects of the action and documenting the context, actions and opinion which were involved. In this phase, the writer collected the data to get information happened in the classroom. The writer adopted the steps in analyzing the data as proposed by Burns (1999). It consisted of assembling, coding, comparing, building meanings and interpretation, and reporting the outcomes. In assembling the data, the writer analyzed the students' problems in writing descriptive paragraph. In coding 
the data, the writer coded the students' writing mistake into the students' problem as mentioned in the planning phase. In comparing the data, the writer tabled the students' mistake into the categories of students' problem as mentioned in the planning phase. Based on the data of the students' writing before they revised the writer's feedback, it can be said that the biggest problem was on providing correct verb, pronoun, determiner, plural, there is and there are. In building meanings and interpretation, the writer checked the students' revision. It was aimed at knowing the students' understanding in correcting their writing and proving the best answers. The results of the students' revision are as follows:

\section{Table 2. The Students' Revision after The Writer Gave Feedback}

\begin{tabular}{|c|c|}
\hline First Writing & Revision \\
\hline Pumanisa was opened. & Pumanisa is opened \\
\hline The students spent & The students spend \\
\hline $\begin{array}{l}\text { Then if colleges or lecturers another } \\
\text { university will say that our canteen had } \\
\text { the best quality }\end{array}$ & $\begin{array}{l}\text { 3. Then if colleges or lecturers } \\
\text { another university will say that } \\
\text { our canteen has.. }\end{array}$ \\
\hline We went to the first floor. & 4. We go to the first floor. \\
\hline This place served & This place serves \\
\hline $\begin{array}{l}\text { Therefore, Pumanisa provided almost } \\
\text { all. }\end{array}$ & $\begin{array}{l}\text { 6. Therefore, Pumanisa } p \\
\text { almost all }\end{array}$ \\
\hline There are many student. & There are many students \\
\hline The customers..... The customers.... & The customers .... They \\
\hline The students..... The students..... & 3. The students ... They \\
\hline On ground floor. & 4. On the ground floor \\
\hline The seller also sell & The seller also sells \\
\hline Sometimes there some students & Sometimes there are \\
\hline ... students, lecturer, ... & .... lecturers \\
\hline Pumanisa have ... & 8. Pumanisa has \\
\hline They are sell .... & 9. They sell \\
\hline Its good for them. & 10. It is good for them \\
\hline $\begin{array}{l}\text { 11. But we should clean the room again } \\
\text { because there are many substances } \\
\text { which is very dangerous for us } \\
\text { sometimes. }\end{array}$ & $\begin{array}{l}\text { 11. But we should clean the room } \\
\text { again because there are many } \\
\text { substances which are very } \\
\text { dangerous for us sometimes. }\end{array}$ \\
\hline Most student ... & 12. Most students.. \\
\hline Pumanisa.... Pumanisa... & 13. Pumanisa ... It ... \\
\hline $\begin{array}{l}\text { 14. Finally, Pumanisa is a big place who } \\
\text { provides }\end{array}$ & $\begin{array}{l}\text { 14. Finally, Pumanisa is a big place } \\
\text { which provides .. }\end{array}$ \\
\hline Pumanisa have three places. & 15. Pumanisa has ... \\
\hline At fisrt floor Pumanisa .. & 16. At the first ... \\
\hline $\begin{array}{l}\text { 17. At the first floor of Pumanisa is also } \\
\text { sells woman clothing. }\end{array}$ & $\begin{array}{l}\text { 17. At the first floor of Pumanisa sells } \\
\text { 18. It also has ... }\end{array}$ \\
\hline It's also have .. & 19. It is a study room. \\
\hline It is study room. & all of them are \\
\hline st all of it is ... & 21. They provide some stands \\
\hline 21. There are provided some stands. & 22. To copy \\
\hline
\end{tabular}


22. To copied

23. There is provided as service

24. Many kind

25. In second floor

26. ... students need ...

27. It is big and large place.

28. There are consist ...

29. During busy time

30. Price in Pumanisa is quiet cheap

31. Pumanisa open

32. It consist

33. If their forgets use socks

34. Two faculty

35. ... lecturer room ..

36. It place has unique ...

37. The building is consists

38. It is open

39. It is give ...

40. The canteen not only serve food and drink but also ....

41. It's can be

42. This place serve for person who want pay ..

1. It can make them like going there.

2. There are always full of students when in the rest time.

3. On the other hand, on the second floor provides like food court.

4. On the third floor uses for study for the students of health.

5. It has many food stalls, coffee shop inside that.

6. It makes colleges and lecturers are easily to buy ...

7. Without go outside campus and buy some of foods or drinks with expensive prices.

8. Then if colleges or lecturers another university will say that our canteen had the best quality.

9. On the last floor, it's just there for rooms.

10. The three rooms for process of learning students.

11. So that place make easy for students to complete their necessary in campus.

12. It is used to teaching and learning activities by a faculty.

13. You can searching, printed, copying your assignments in there.

14. But sometimes difficult to find ...

15. To have eat

16. Many people in there

17. Just the students of the doctor can
23. They provide ...

24. Many kinds

25. At the second floor

26. ... students' need ...

27. It is $a$ big and large place

28. They consist ...

29. During the busy time

30. The price in Pumanisa ..

31. Pumanisa opens

32. It consists

33. If they forget use ...

34. Two faculties

35. ... lecturers' room ...

36. Its place has unique ...

37. The building consists

38. It opens

39. It gives

40. The canteen not only serves food but also ...

41. It can be

42. This place serves for person who wants to pay

1. It makes them there

2. It is full of students at the break time

3. On the other hand, at the second floor is the place of food court

4. The third floor is used for medical students.

5. It has many food courts

6. It makes the colleges and lecturers easily to buy ..

7. They don't need to go out to have some food and drink. The price in Pumanisa is cheaper than other canteen.

8. Our canteen is the best

9. At the third floor, it has many rooms

10. The third room is for conducting the teaching and learning process

11. It helps students to buy everything easily

12. It is used to handle the teaching and learning process

13. You can search, print, copy your assignment there

14. But sometimes it is difficult to find..

15. To eat

16. Many people there,

17. The room is only for the medical students 
enter in that room

1. It can make them like going there.

2. This is completely necessary for colleges to buy something effectively.

3. The students can be used to talk with their friends and there is very crowded.

4. Skin can their buy in first floor

1. Students who haven't their breakfast.

2. Multi function canteen because ...

3. ... make an assignment, but we don't have enough time.

4. It is used to teaching and learning activities by a faculty.

5. But sometimes difficult to find ...

6. The sellers very busy

7. In second floor many canteen you can buy food and drink

8. All of the people need something to office tool must buy to the first floor.

9. Pumanisa is a place that very comfortable.
1. It makes them there

2. It makes the students easily to buy everything

3. It can be used to have discussion with their friends

4. At the first floor, students can buy their daily needs

1. Students who haven't had their breakfast

2. It is a multi function canteen because

3. ... do assignment but we don't have enough time

4. It is used by another faculty

5. But sometimes it is difficult to find ...

6. The sellers are very busy

7. At the second floor, there are many food court that you can choose and you can buy your food there

8. People who need office needs can have it at the first floor

9. Pumanisa is a place that is very comfortable

1. We know that usual canteen is only served food.

1. We know that common canteen only serves food

2. On the third floor uses for study for the students of health.

2. The third floor is used by the medical students

3. There are provided some stands

4. It located ....

3. There are some stands

4. It is located

5. The mini market in first floor located in front of ...

6. The third floor is use for ...

5. The mini marker is at the first floor which is located in front of

6. The third floor is used for

7. The room is completed by ..

7. Inside the room is complete ....

1. Floor two, floor three, ...

2. Equipment lecture

3. $\ldots$ has own part ...

4. If their forgets use socks

5. Second floor is the place I thing.

6. I don't know much for this room.

$\underline{7 .}$ First floor for necessary students and staff

1. You can searching, printed, copying your 1. You can search, print, copy your assignments in there.

2. You can finding....

3. We can using .....

1. It is the central canteen. Therefore, every faculty provides small canteen also.

2.In there, so many comfortable tables and chairs that we can enjoy our talking. And order food and drinks that we want.
1. The second floor, the third floor

2. Lecture's needs

3. ...has its part ...

4. If they forget to wear socks

5. The second floor is the place I think

6. I don't know more about this room

7. The first floor is for daily needs assignment there

2. You can find

3. We can use

1. Even it is the central canteen, we can find some small canteen in some faculties.

2. There are many comfortable tables and chairs 


\begin{tabular}{|c|c|c|c|c|c|}
\hline & $\begin{array}{l}\text { Students (in the previous sentences) } \\
\text { student (in another sentences) }\end{array}$ & 1. & $\begin{array}{l}\text { Students } \\
\text { sentences) }\end{array}$ & every & single \\
\hline $1 \ldots$ & . collage .... & 1. & College & & \\
\hline 2. & ..... healt ..... & 2. & Health & & \\
\hline 3. & ..... conclution ..... & 3. & Conclusion & & \\
\hline 4. & $\ldots . \overline{\text { coffe } \ldots . . .}$ & 4. & Coffee & & \\
\hline 5. & 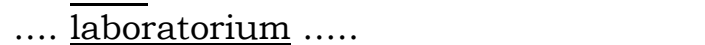 & 5. & Laboratory & & \\
\hline 6. & $\ldots$ equipmen $\ldots$. & 6. & Equipment & & \\
\hline 7. & .... pensil .... & 7. & Pencil & & \\
\hline 8. & .... strategis .... & 8. & Strategic & & \\
\hline & $\ldots$ jilid .... & 9. & Bandle & & \\
\hline 10 & .... complit .... & 10. & Complete & & \\
\hline 11. & .... foto .... & 11. & Photo & & \\
\hline
\end{tabular}

As the last step, in reporting the outcomes, the writer reported the data. Based on the students' revision above, it can be said that they understood the feedback easily. Hence as the result, they could understand the feedback given by the writer. As the last feedback, the writer gave back the students' writing and wrote certain reinforcement sentence to show that the students had understood their problem.

Finally, the writer came to the last phase, reflecting phase, the phase in which the writer used the writer's creative insights, thoughts and understanding about the process and the finding of the research. Therefore, the writer needed to decide whether or not the writer had to handle the next cycle. Here, the writer reflected, evaluated, and described the effects of the action in order to make sense of what had happened and to understand the issue that the writer had explored more clearly. The results of the reflection was that the writer did not decide to have further cycles since the students have understood their mistake and they put the appropriate answers on their revision. It can be said that the process of giving and receiving feedback made the students' understand their problem and through feedback they followed the thinking process.

The result of the feedback application on the second semester students' writing brought the writer into the discussion of the research. It can be discussed that the biggest problem of the second semester students was on the capability of providing correct verb, pronoun, determiner, plural, there is and there are. The process of revising the descriptive paragraph writing, the 
students did different ways. The students who were not capable of deciding the appropriate tense, they opened their grammar book to make the revision.

The students who had understood in proving correct verb, pronoun, determiner, plural, there is and there are; they did not need to ask their friends or even open dictionary. The students who were not capable of changing Indonesian sentences into English sentences, they asked their classmate to find the English similar sentences. The students who were not capable of creating meaningful sentences, they asked their friend to give them idea but not to give the correct answers. The students who were not capable of creating complete sentences, they opened their grammar book, dictionary and there are some students who asked their friends to find the solution. The students who were not capable of providing active into passive sentences and vice versa, they opened their grammar book to differentiate between active and passive sentences. The students who were not capable of deciding the appropriate words choice, they opened their dictionary. The students who were not capable of creating good sentences which consists of modal, they opened and read their grammar book. The students who were not capable of creating uncorrelated sentences they rechecked their previous sentences and found their meaning before the revised the uncorrelated sentences. The students who were not capable of creating correct direct-indirect sentences they opened and understood the material of it from their grammar book. The students who were not capable of creating consistent terms, they reread the paragraphs and changed the dissimilar words into similar words. The students who were not capable of creating correct English words, they opened their English dictionary.

Every student had different problems and different ways of revising their inappropriate sentences. The process of understanding the feedback given by the writer and providing the appropriate answers made them could provide better writing.

\section{CONCLUSION}

Based on the result of the research, the writer concludes that the application of indirect feedback was very useful and helpful to improve the 
Maharani, The Application of Indirect Feedback to Improve Students'...

students' writing in descriptive paragraph. There were many ways of revising the feedback done by the students. There were students who used dictionary to check the words choice and inconsistent words used. There were students who used their prior knowledge of the previous writing or grammar subject to open up their memory of those subjects in order to get better writing. The students' writing revision shows that the students understood how to make their writing better. The underlined words as the symbols of the indirect feedback helped the students to revise their misleading writing correctly. Through the indirect feedback, the students' paragraph writing was more understandable since they could provide the meaningful sentences.

\section{REFERENCES}

Bailey, S. (2003). Academic writing: a practical guide for students .Routledge Falmer.

Burns, A. (2010). Collaborative action research for English language teachers.UK: Cambridge University Press.

Cohen, R.F. \& Miller, J.L. (2001). Reason to write: Strategies for success in academic writing. Oxford: Oxford University Press.

Maarek, S. (2009). The effectiveness of correction symbols as feedback in enhancing self-correction in writing (Master degree). Mentouri University of Constantine.

Nunan, D. (2003). Practical English language teaching. (1 ${ }^{\text {st }}$ ed.). New York: McGraw-Hill Companies, Inc.

Oshima, A. \& Hogue, A. (2006). Introduction to academic writing. (3 ${ }^{\text {rd }}$ ed.). New York: Addison Wesley Longman, Inc.

Rachmajanti, S \& Sulistyo, G.H. (2008). Strengthening the teaching of English in lower secondary schools: Towards teacher professional development. Unpublished Textbook. English Department of Letters Faculty of State University of Malang, Malang.

Ravand, H. \& Eslami, R. (2011). Feedback in ESL writing: Toward an interactional approach. Journal of Language Teaching and Research, 2 (5), 1136-1145.

Richards, J. C., \& Schmidt, R. (2002). Language teaching and applied linguistics. Pearson Education Limited. 
Thanatkun, T. (2008). Integrated approaches to improve students' writing skills for English major students. ABAC Journal, 28 (2), 1-9.

http://www.journal.au.edu/abac_journal/2008/may08/01/1-

9)_article01.pdf. 